
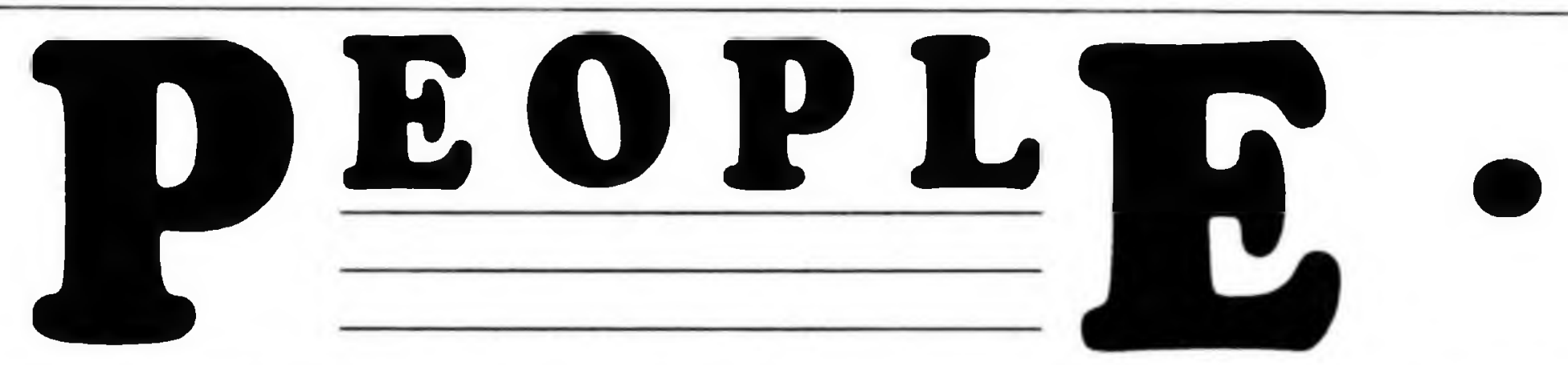

\section{Profiles}

Carol Fleishauer, chief of the Acquisitions Department at Stanford University since 1986, is now the associate director for collection management and technical services at the Massachusetts Institute of Technology, Cambridge. She has been a member of the Stanford University Libraries staff for ten years, beginning her career in the Catalog Department as head of copy cataloging and later as assistant chief. In March 1985, she was named acting chief of acquisitions.

Robert P. Holley, assistant director for technical services at the University of Utah, has been named associate dean of the Wayne State University Libraries, Detroit.

Holley has also held several key positions at Yale University, including head of the Social Science Section, Subject Cataloguing Division, and assistant to the head of Cataloguing at Yale's Sterling Memorial Library. A summa cum laude graduate of Xavier University, Holley earned his MLS from Columbia University

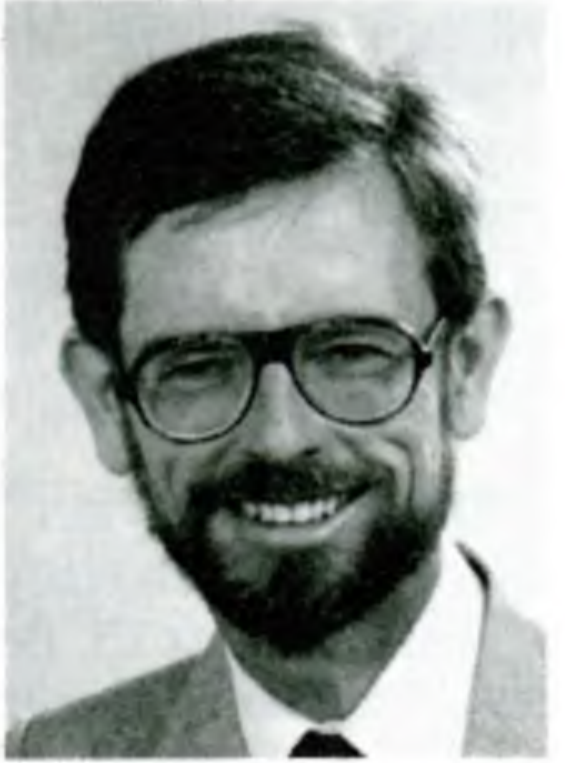

Robert P. Holley and a doctorate in

French literature from Yale University. His articles and reviews have appeared in numerous professional journals and he is active in the American Library Association, the International Federation of Library Associations, and other organizations. He has also received the Technical Services Section Distinguished Service Award of the Utah Library and the Tauber-Begner Award in Technical Services at Columbia University.

KathleEn Kosuda, assistant director of the East Pasco County school library since 1987, is the new director of the Daniel A. Cannon Memorial Library at Saint Leo College, Florida. She holds a bachelor's degree and an MLS from the State University of New York at Albany. She previously worked as librarian at Pasco-Hernando Community College, New Port Richey, and was director of the Gloversville Free Library, New York, for six years. She worked as reader services librarian at the Saint Leo College Library from 1983 to 1987. Kosuda is a member of the American Library Association, the Florida Library Association and the Catholic Library Association, and is past president of the West Pasco Branch of the American Association of Women.

Ruth J. Person, dean of the College of Library Science at Clarion University of Pennsylvania since 1986, has been named associate vice chancellor for curriculum and personnel at the University of Missouri, St. Louis, effective October 3. She had previously held several appointments at the Catholic University of America during 1979 to 1986, including service as associate dean of the School of Library and Information Science from 1983 to 1986 and assistant professor from 1979 to 1983 . Prior to

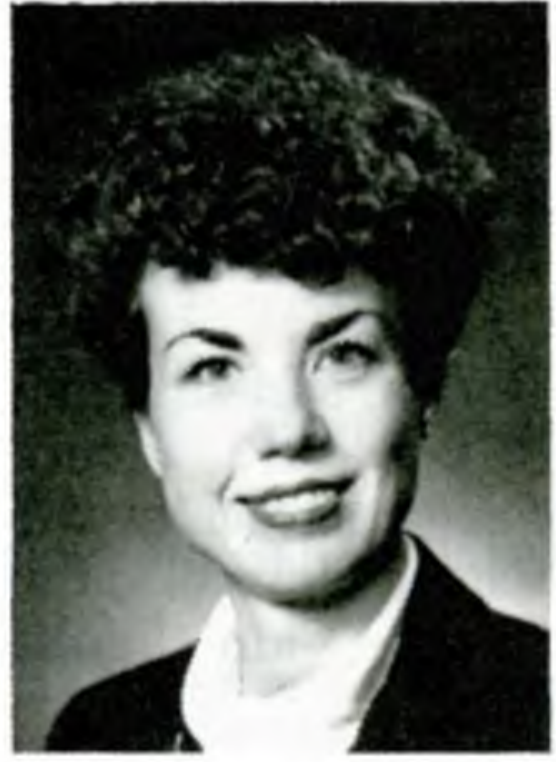

Ruth J. Person 1979, Person served as both a lecturer at the University of Michigan's School of Library Science and as coordinator of library science continuing education for the University Extension Service; she also was project director of the Public Library Energy Education Project. From 1969 to 1971 she was a reference librarian in the Burton Historical Collection at the Detriot Public Library, and from 1971 to 1974 she served as head of reference at Thomas Nelson Community College in Hampton, Virginia.

Person has written and published a number of research articles and reviews for Advances in $\mathrm{Li}$ brary Administration and Organization, College and Research Libraries, Library Trends, Community and Junior College Libraries, the Higher Education Bibliographic Yearbook, and Reference Books Bulletin. She is editor of The Management Process (ALA, 1983), and has had additional articles published in the LAMA publications, Staff Development in Libraries (1984) and Training Issues in Changing Technology (1986). She has frequently given talks or presented papers at confer- 
ences and meetings and has served as a workshop leader on numerous occasions. She recently completed an ARL Occasional Paper, Selection of the University Librarian (1988).

Person is active in state and national library and educational associations, she has served as chair of ALISE Continuing Education Committee and on the Manuscript Review Committee of the National Association of Women Deans, Administrators, and Counselors. Within ALA she serves as chair of the ACRL Publications Committee, was chair of the ACRL Professional Education Committee from 1984-1986, and on the Editorial Board of Reference Books Bulletin from 1981-1985. Person is also a current member of the ALA Publishing Committee and the LRRT Board.

She is also a member of numerous societies, including Beta Phi Mu, Pi Lambda Theta, Kappa Delta Pi, and Psi Chi. In 1976, she was a Rackham Fellow at the University of Michigan, and in 1986 was named a "Washington Woman of the Year" by Washington Woman Magazine.

Ann E. Prentice, director and professor at the Graduate School of Library and Information Science since 1978, University of Tennessee, Knoxville, has been named associate vice president for libraries and information resources at the University of South Florida, Sarasota. From 1972 to 1978 , Prentice was on the faculty of the School of Information Science and Policy SUNY at Albany.

She holds a bachelor's degree in political science (1954) from the University of Rochester, an MLS (1964) from

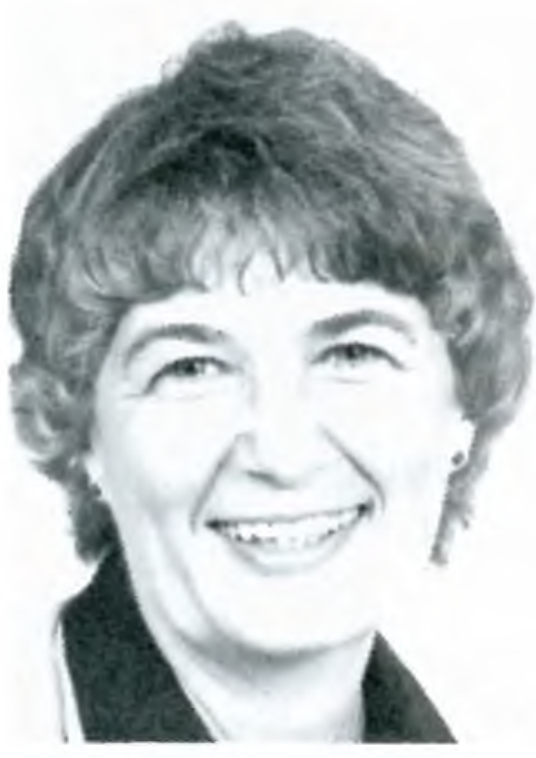

Ann E. Prentice SUNY at Albany, and a doctorate (1972) from Columbia University. She was a participant in the Women in Higher Education Administration Institute at Bryn Mawr (1986), a Council on Library Resources Fellow (1983), and was awarded an honorary Doctor of Letters degree from Keuka College (1979).

Prentice has also been a consultant on a variety of topics in the library and information science field, has led several research projects, and has published numerous books and articles dealing primarily with library management and long-range planning. She is associate editor for the Library and Information Science Annual, published by Libraries Unlimited.

Prentice has served as an ALA councilor, and is currently a member of the ACRL Planning Committee and ALA's Intellectual Freedom Committee. She was president of the Association of Library and Information Science Education in 1986, and is a member of the Board of Directors of the American Society for Information Science for 1985-1988. She is an active member of the Tennessee Library Association and the Southeastern Library Association.

Cerise Oberman, public services planning officer at the University of Minnesota, Twin Cities, has been named director of libraries at the State University of New York at Plattsburgh,effective August 1. Oberman received her bachelor's degree from SUNY at New Paltz (1973) and her MLS (1976) from Emory University. In 1974 she served as reference librarian and then head of reference at the College of Charleston, South Carolina. During her years at the College she organized the Southeastern Conference of Approaches to Bibliographic Instruction and edited the proceedings. In 1981, Oberman served as head of reference at the University of Minnesota's Walter Library. In 1985 she was appointed to the newly created position of public services planning officer for the Twin Cities Libraries. She was responsible for planning and policy for University Libraries system-wide information and access services.

Oberman has published numerous articles on library instruction and learning theory. She is coeditor of Theories of Bibliographic Education: Designs for Teaching. Oberman has been an ACRL workshop leader for continuing education courses since 1982 as well as a frequent speaker at state and regional conferences. She has served as a member of the ACRL Bibliographic Instruction Section Executive Committee since 1985 and has recently been elected vice-chair/chair-elect of ACRL/BIS.

Donald G. Sweet has been named library director at the University of Arkansas at Little Rock, effective August 15. Before coming to Little Rock, Sweet served as director of the university library at the University of Wisconsin at River Falls and, from 1984 to 1987 , served as university librarian at Prairie View A\&M University, a part of the Texas A\&M sytem. He was also head librarian at the Altoona campus of the Pennsylvania State University from 1981 to 1984 and was director of the li-

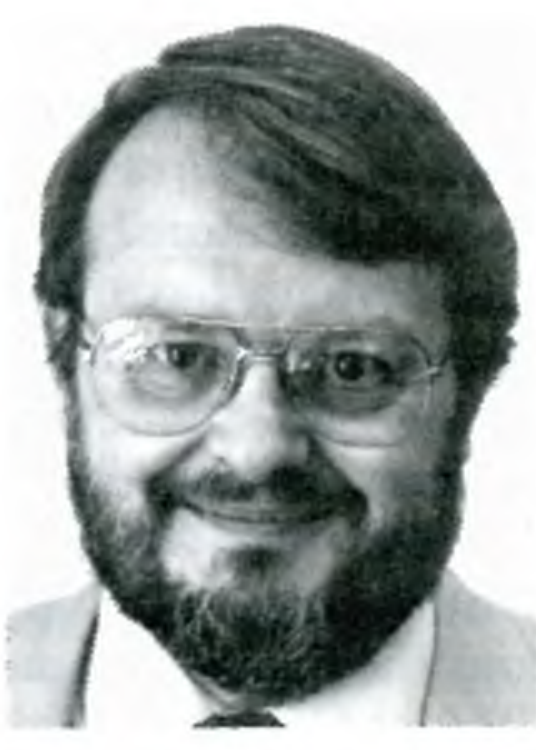

Donald G. Sweet brary at Milton College in 1980-1981.

He holds a doctorate in philosophy from the State University of New York at Buffalo (1976) and an MLS from the University of Wisconsin at Milwaukee (1979).

Sweet serves as an international editor for $\mathrm{Li}$ brary Times International and sits on the LAMA 
Building and Equipment Section's Standards for Physical Space Requirements for Libraries Committee.

\section{People in the news}

LELAND S. DutTon, former director of libraries at Miami University, Ohio, received an honorary Doctor of Humane Letters degree at the annual commencement program at Miami University last May. His efforts in expanding the library's collections and in establishing the library at Miami's European Center in Luxembourg were mentioned in the citation. In 1984 the University had also recognized his contributions to the library system when the south wing of King Library was dedicated as the Leland S. Dutton Wing.

Barbara Fischer, director of university libraries at Indiana University-Purdue University, Indianapolis, was recently named Outstanding Librarian for 1988 by the Indiana Library Association and the Indiana Library Trustees Association.

IrWin H. Pizer, university librarian for the health sciences at the University of Illinois at Chicago, has been appointed editor of the Bulletin of the Medical Library Association. The first issue under his editorship will be the January 1989 issue.

IsABEL STIRLING, head science librarian at the University of Oregon, Eugene, has been awarded a four-month fellowship by the American Library Association to teach graduate students in Turkey online database searching in Dialog and other sci/ tech databases. The fellowship, provided by a renewal grant from the U.S. Information Agency, allows ALA to continue its Library/Book Fellows program, which places U.S. library and publishing professionals in overseas institutions for up to one year. Stirling will teach at the Documentation Center of the Higher Education Council of Turkey and the Hacettepe University School of Library Science in Ankara.

VICKI WATKINS, manager of the Business Information Service at the Walker Management Library, Vanderbilt University, Nashville, is the recipient of the "1988 Disclosure Achievement Award for Excellence in Information and Library Management." The award is presented annually to a member of the Business and Finance Division of the Special Libraries Association who has made a significant contribution to a library or to the library community in general.

ROBERT G. VOSPER, professor emeritus and librarian emeritus of the UCLA Graduate School of Library and Information Science, was awarded the UCLA Medal, the university's highest honor, at the 1988 commencement ceremony. The UCLA Medal is presented to persons who have achieved distinction in the humanities, arts, or sciences. Vosper, a past president of ALA, is an internationally recognized expert on the development of research facilities. He was appointed the first assistant university librarian at UCLA in 1948 and, one year later, the first associate university librarian. He became director of UCLA's William Andrews Clark Memorial Library in 1966. Others who were awarded the UCLA Medal at the same ceremony were film director Robert Wise, and the president of the National Academy of Sciences, Frank Press.

\section{Appointments}

(Appointment notices are taken from library newsletters, letters from personnel offices and appointees, and other sources. To ensure that your appointment appears, write to the Editor, ACRL, 50 E. Huron St., Chicago, IL 60611-2795.)

Stephen H. Aby has been appointed education bibliographer at the University of Akron, Ohio.

James C. AKIns has been appointed assistant librarian at Eastern New Mexico University, Portales.

Ivan Arguelles is now librarian in the Catalog Department at the University of California, Berkeley.

Ross ATKINSOn has been appointed assistant university librarian for collection development and preservation at Cornell University.

Roger BECKMAN has been appointed assistant librarian in the Chemistry Library at Indiana University, Bloomington.

LESLIE BERwICK has joined the staff at the University of New Mexico's Medical Center Library.

MARY S. Bopp has been appointed visiting assistant librarian in the Reference Department at Indiana University, Bloomington.

KAY BRADT is now associate librarian at Baker University, Baldwin, Kansas.

Heather J. E. Braithwaite has been named assistant director of Neef Law Library at Wayne State University, Detroit, Michigan.

SANDRA BraY has been appointed acquisitions order librarian at Arizona State University, Tempe.

Donald L. Breneau has been named assistant director of Purdy/Kresge Library at Wayne State University, Detroit, Michigan.

R. MARILYN Brown has been appointed catalog librarian at Wingate College, Wingate, North Carolina.

Dennis Brunning has been appointed reference librarian/coordinator of computer services for the social sciences and humanities at Arizona State University, Tempe.

Marsha Anne Butier has been appointed clinical medical librarian at the University of Missouri, Kansas City.

Betsy Carter has been appointed librarian at the Citadel Library, The Citadel, Charleston, South Carolina.

VIrgINIA CASSADY has been appointed catalog librarian at Arizona State University, Tempe.

Cathie Chiu has been appointed Chinese language cataloger at the University of Colorado, 
Boulder.

ANITA CoHEN has been appointed reference librarian/subject specialist for anthropology, sociology and social work at Arizona State University, Tempe.

Robert Congleton is now the acquisitions/serials librarian at Temple University, Philadelphia, Pennsylvania.

ANNa LeE CoOKe has been appointed head librarian at Lane College, Jackson, Tennessee.

Sheila Curl has been appointed science reference librarian/engineering subject specialist at Arizona State University, Tempe.

MARY DEANE has been appointed evening reference librarian for Florida International University, North Miami Campus.

ANDREa C. Des Jardins is the new assistant curator of the Visual Collections in the Fine Arts Library, Harvard University.

Pam Drayson has been appointed director at Kansas City Community College, Kansas.

GLENDA DRIGgs has been appointed librarian at Tarkio College, Tarkio, Missouri.

LAILA EL-ZEIN is now head of the Bibliographic Services Department at Temple University, Philadelphia, Pennsylvania.

PATricia ETter has been appointed assistant archivist for database services at Arizona State University, Tempe.

David FeinberG has been appointed evening reference librarian for Florida International Uni-

\section{Bibliometric papers wanted}

The Fall 1989 special issue of Communication Research will focus on "Bibliometric Methods for the Study of Scholarly Communication." Papers on the topic, which encompasses the quantification of bibliographic data, might address the following questions: What contributions have bibliometric methods made to the study of scholarly communication in the past, and what role should or will they play in the future? What is the relationship among the different methods currently being applied to the study of scholarly communication? Can these methods be brought together in a single paradigm?

The deadline for submitting a paper is November 1, 1988. Authors whose manuscripts are accepted for publication will be notified by January 15, 1989. All papers and correspondence should be sent to Christine L. Borgman, Associate Professor, Graduate School of Library and Information Science, University of California, Los Angeles, CA 90024; (213) 8251379.

Communication Research is an international journal that publishes research on scholarly communication, organizational communication, and new information technologies. versity, University Park Campus, Miami.

Mark FLYNN is now associate librarian for special collections and archives at George Mason University, Fairfax, Virginia.

JENNIFER GERAN is now interlibrary loan librarian at Rice University, Houston.

JEFFrEY GILDERSON-DUWE is now social sciences reference librarian at the University of Missouri, Kansas City.

Mary LOU GoOdyear has joined the staff at the Iowa State University Library, Iowa City.

MiCHELle Gotz has been appointed music/fine arts librarian at Wichita State University, Kansas.

CONNIE Jo HARDY has been appointed public services librarian in the Education Library at Vanderbilt University, Nashville, Tennessee.

MaRY HEATH is now the library systems development officer at the University of California, Davis.

Julie Ann Hendon has been appointed indexer in the Tozzer Library at Harvard University.

VICKI HeNDricks has been appointed reference librarian/business subject specialist at Arizona State University, Tempe.

ThomasJ. Hinders has been appointed cataloger at the University of Akron, Ohio.

COlleEn Hyslop is now head of Technical Services at Michigan State University, East Lansing.

BETTY JARBOE is now the acting head of the Reference Department at Indiana University, Bloomington.

MARGaret A. JOHNSON has been appointed library director at the University of Minnesota, Duluth, effective December 1, 1988.

Danny Jones has been appointed assistant library director for collection development at the University of Texas Health Science Center at San Antonio.

Phyllis Kalmenton has been appointed technical services librarian at Palmer College of Chiropractic, Davenport, Iowa.

LYNETTE KORENIC is the new head of the Arts Library at the University of California, Santa Barbara.

LYDIA LAFARO has been appointed reference librarian/business subject specialist at Arizona State University, Tempe.

RENEE J. LAPERRIERE has been appointed bibliographic instruction librarian at Eastern New Mexico University, Portales.

SuZANne T. LARSEN has been appointed head of the Earth Science Library at the University of Colorado, Boulder.

MARY LARSGAARD has been appointed associate librarian of the Map and Imagery Laboratory at the University of California, Santa Barbara.

AnN LATTA is the new assistant chief of the Jonsson Library of Government Documents, Stanford University, California.

JANNA LAWRENCE has been appointed information services librarian at the University of Texas Health Science Center at San Antonio.

WENDELL LOTZ has been appointed marketing 
director for school and academic libraries at Baker \& Taylor, Bridgewater, New Jersey.

Maryellen Powers McCarthy is the new head of Circulation Services in the Littauer Library at Harvard University.

NANCY MCCLEMENTS is the new reference librarian at Memorial Library at the University of Wisconsin, Madison.

SCOTT MACFARLAND has been named president and CEO of the Faxon Company, Westwood, Massachusetts.

Nancy S. MaCKeChNiE is now curator of Rare Books and Manuscripts at Vassar College, Poughkeepsie, New York.

Yolanda C. MaLoneY has been appointed assistant business librarian at the University of Colorado, Boulder.

JoHn MaXymuk has been appointed coordinator of computerized reference services at Temple University, Philadelphia, Pennsylvania.

Margaret V. Mering has been appointed supervisor of the Serials Department Cataloging Unit at the University of Colorado, Boulder.

Rosemary Meszaros has been named assistant librarian for government publications at the University of California, Santa Barbara.

JAMES Miesse is now user services librarian at NOTIS, Evanston, Illinois.

LYDIA MILLER has been appointed clinical medical librarian at the University of Missouri, Kansas City.

Rachel Miller has been appointed head of the Acquisitions Department at the University of Kansas, Lawrence.

Hideyuki Morimoto has been appointed Japanese language catalog librarian/area specialist at Arizona State University, Tempe.

DENISE MORRISON is now archivist at the Kansas City Museum, Missouri.

Christine Mote has been appointed catalog management librarian at Arizona State University, Tempe.

ERIN MURPHY is the reference and collections development librarian at the University of Waterloo, Ontario, Canada.

BERNA NEAL is now head of the Architecture and Environmental Design Library at Arizona State University, Tempe.

DANiEL P. O'MAHONY has been appointed government publications librarian at the University of Colorado, Boulder.

Jean Kudo Pearce has been appointed readers' services librarian at Wheaton College, Norton, Massachusetts.

Richard Pearce-Moses is now assistant archivist for the photographic collections at Arizona State University, Tempe.

Dennis R. Peterson has been appointed director of the Health Sciences Library, Palmer College of Chiropractic, Davenport, Iowa.

JoYCE Plaza is now science reference librarian/ coordinator of computer services for the sciences

\section{Tough
Questions?}

E

very day, you're challenged by tough questions.

Where can I get a chronology of the Iran arms-Contra aid scandal? What legislative steps is Japan taking to remove import quotas and other non tariff trade barriers in response to U.S. and EEC criticism?

If your users want the answers to these and other public policy questions, it's time to search PAIS.

PAIS is the foremost indexing service covering national and international political, economic, and social issues. It's the unique, one-stop resource that gives you immediate access to a huge, eclectic range of material, including books, periodical articles, directories, government documents, statistics, and much more. And it's the only index of its kind that covers literature published around the world in English, French, German, Italian, Portuguese, and Spanish.

Where are your searches consistently productive, adding a valuable dimension to your research efforts? Where do you find answers to the toughest questions? Easy ... . PAIS!

PAIS is available in print, online, and now via $\mathrm{CD}-\mathrm{ROM}$. For information, call 800-841-1416. In New York or outside the continental U.S., call 212-736-6629.

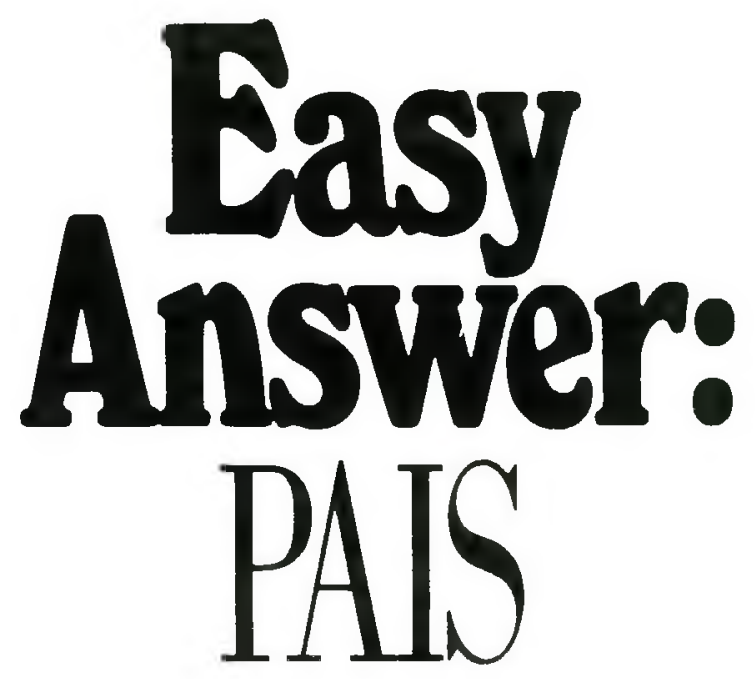

Public Affairs Information Service 11 W. 40 Street

New York, NY 10018-2693 
and engineering at Arizona State University, Tempe.

Pamela B. RadCliffe has been promoted to systems librarian at Francis Marion College, Florence, South Carolina.

BETSY REDMAN is now acquisitions receipt librarian at Arizona State University, Tempe.

Robert J. Rittenhouse has been appointed physical sciences and engineering bibliographer at the University of Akron, Ohio.

WANDA SUE RoIIRBough has been named health sciences reference librarian at Ohio University, Athens.

JUDY SCHACHTER is the new circulation librarian at the University of Wisconsin, Madison.

SHIRLEY R. ScotT is the new head of research services at Oregon State University, Corvallis.

T. C. SHIH has been appointed assistant head of social science and humanities reference and database coordinator at Michigan State University, East Lansing.

Suzanne Singleton has been appointed assistant reference librarian at the Francis Marion College, Florence, South Carolina.

Robert SPINDLER has been appointed assistant archivist for manuscripts/field collector at Arizona State University, Tempe.

JAN S. SQuIRE has been appointed reference/serials lilbrarian at the University of Northern Colorado, Greeley.

Claudell Smith Stocker has been appointed head of the Braille Development Section at the National Library Service for the Blind and Physically Handicapped, Library of Congress, Washington.
Jennifer Sturgis has been appointed science reference librarian at Fenwick Library, George Mason University, Fairfax, Virginia.

RUTH K. TAYLOR has been named assistant director of Shiffman Medical Library at Wayne State University, Detroit, Michigan.

George Terry has been appointed associate vice president for libraries and collections at the University of South Carolina, Columbia.

BoB WALTER is now library director at Pittsburg State University, Kansas.

JOHN W ANSERSKI has been appointed science reference librarian/physical science subject specialist at Arizona State University, Tempe.

JAMES M. WETHERBEE has been appointed reference librarian at Wingate College, Wingate, North Carolina.

Allan Wenzel is the new instructional program manager at the University of Wisconsin, Madison.

SuSAN Willcox has been appointed circulation/interlibrary loan librarian at the University of Texas Health Science Center at San Antonio.

\section{Retirements}

Shimeon Brisman, Jewish studies bibliographer at the University of California, Los Angeles, has retired after 26 years of service.

JENNIE BRoGDON, head of the Reference Branch of the Public Services Division at the National Agricultural Library, Beltsville, Maryland, has retired after 18 years of service. She served four years in her present position, and implemented reference

\title{
RESEARCH PUBLICATIONS
}

\section{Guaranteed availability, when you want them.}

\author{
Journals of Science, Technology, \\ and Medicine in microform.
}

Every title filmed and delivered - from the first issue forward. Current subscriptions are delivered within three months of the end of the volume year, and availability of all backfiles is guaranteed. For complete title listings and prices, call 1-800-REACH-RP (1-800-732-2477) now. From Connecticut, Alaska and Canada, call collect (203) 397-2600.

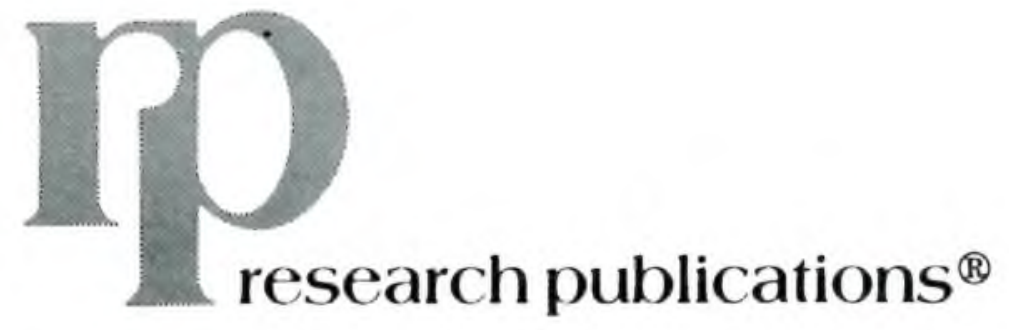


reorganization for Economics and Marketing in 1984 , and for all of reference in 1987. She served in a variety of positions at NAL in the lending and other public service positions over the years, including head of the Utilization Department from 1976-1984. Before coming to NAL, she worked for 12 years as a food technologist in USDA's Human Nutrition Research Division, and for the Entomological Society of America. Brogdon earned her bachelor's degree in home economics and her MLS at the University of Maryland in 1970.

Anna LeE Cooke, head librarian at Lane College, Jackson, Tennessee, retired August 1, 1988, after 25 years of service. Cooke began as a cataloger at Lane and assumed library directorship in 1967. Before coming to Lane she served as a secondary school librarian with the Jackson, Tennessee, school system for 12 years. During 1972-74, she served on the ACRL Standards and Accreditation Committee. She has been a continuous member of ALA since 1960 and ACRL since 1963. In 1982 she was commissioned to write the history of Lane College which was published in 1987.

Arthur N. Cronizes, catalog librarian at the Daniel Library, the Citadel, Charleston, South Carolina, retired this summer.

Leroy Fox, librarian at the Johnson County Public Library, Kansas, has retired.

JuDITH LEVY, director of the Health Science Information Service has retired after serving eight years at the University of California, Berkeley. She came to UC Berkeley after working in medical research at both Case Western Reserve and UC Medical Center in San Francisco. She also taught in the San Francisco School District. After receiving her MLS she was a children's librarian and then medical librarian for the Health and Welfare Department of the County of San Mateo. While working half-time as the HSIS director, she also served as library consultant to Cowell Hospital, Chair of the Staff Development Committee, was a CAPA member, and was actively involved in faculty seminars. Levy also was on the board of the UC Berkeley Library school Alumni Association, and in 1983, she also worked half-time as a reference librarian in the Public Health Library for nine months. She has been active in Bay Area professional organizations, the Northern California and Nevada Medical Library Group, chaired the Continuing Education Committee, and the Professional Development Committee.

Clinton Lockert, Michigan State University Libraries, East Lansing, retired on June 30, 1988, after 34 years of service.

Carolyn McMillen, Michigan State University Libraries, East Lansing, retired on June 30, 1988, after 23 years of service.

Donald J. Pearce, director of the University of Minnesota Library, Duluth, will be going on phased retirement while working on the bibliography and public relations of the Ramseyer-Northern Bible Society Museum Collection, held by the
UMD Library.

Jean Posey, cataloger at the Penn Valley Community College, Kansas City, Missouri, has retired.

JoHn VANDERMOLEN, library staff at Auburn University, Alabama, has retired.

William J. Welsh, deputy Librarian of Congress, Washington, D.C., since February 1976, retired on October 3 after more than 40 years of service. Welsh began his career with the Library of Congress in 1947. Among the programs which he has initiated were the optical disk pilot project and the Library's development of the diethyl zinc deacidification process. He was also was closely associated with the automation and filming of the Library's catalogs, the Library's Intern Program, the division chief's luncheons (forums for managers to exchange information on professional concerns), and Executive Session.

Welsh has served as the Library's representative in national and international library circles, as chair of the Conference of Directors of National Libraries, and as a member of the American Library Association, the Commission on Preservation and Access, and the Foundations Group Library Committee. He has served as the Library's representative to the Association of Research Libraries, on the National Commission on Libraries and Information Science, and on the Board of Regents of the National Library of Medicine. Welsh has chaired ALA's John Ames Humphry/Forest Press Award jury for the past two years. In 1979 he headed the first official delegation of American librarians to China following the resumption of official diplomatic exchanges.

In March 1947 Welsh began his career with the Library of Congress as a searcher in a postwar project for cooperative acquisitions. He has served as head of the Order Unit and Order Section, head of the East European Accessions Index project, executive officer of the Processing Department, associate director of the Administrative Department, and associate director of the Processing Department. In May 1968 he was named director of the Processing Department. His work in that capacity earned him the ALA Melvil Dewey Award in 1971. He received many other honors and awards, including in 1983 the Library's Distinguished Service Award, an honorary degree of Doctor of Laws from the University of Notre Dame in 1984, and honorary membership in the Special Libraries Association and the University of Michigan's School of Information and Library Studies, both in 1988.

Welsh earned his bachelor's degree from the University of Notre Dame in 1940 and pursued studies in law at Notre Dame before he began service in the U.S. Air Force from 1941-1947.

Betty Willson, acquisitions librarian for the Southeast Kansas Library System, Iola, has retired. 


\section{Deaths}

Donald J. Coombs died July 3, 1988. Prior to earning an MLS, Coombs worked as a methods analyst for Lockheed Aircraft in Marietta, Georgia. He then became a public relations account executive for O.S. Tyson in New York, 1955-1958 and 1960-1961, and from 1962 to 1964 , he was the chief editor for Polaris Publications, Lockheed Missiles, in Sunnyvale, California. During that time he was also a free-lance editor of textbooks for Harcourt, Brace. After earning his MLS from the University of California, Berkeley, in 1965, he served as assistant university librarian for technical processing at the University of Southern California in 1970-1974, an adjunct faculty member at the

\section{ANNOUNCING A VERY SPECIAL. SYMPOSIUM}

\section{What}

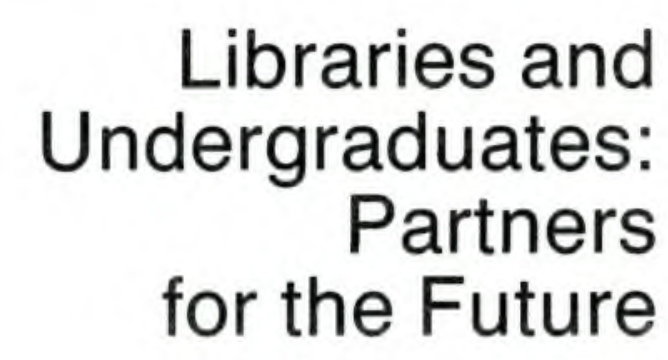

When

December 4-5, 1988

\section{Where}

University of Michigan Undergraduate Library

\section{Speakers}

Virginia Tiefel
Sharon Hogan
Marion Marzolf
Betsy Wilson
Nancy Allen

For more information call Barbara MacAdam University of Michigan 313-763-5084
School of Library and Information Studies at the University of California, Berkeley, in 1973, and acquisitions librarian at the University of San Francisco. He joined the staff of Coutts Library Services in 1975 , calling on academic librarians in the western states. He had earned two degrees from UCLA and completed coursework and examinations for a Ph.D. He was a member of Phi Beta Kappa, and was active in ALA, the California Library Association, and the Special Libraries Association.

George Davis, reference librarian at the San Francisco City and County Law Library, died July 24, 1988. He previously worked for the University of California, Berkeley, as head of the Governments Documents Department from 1966 to 1975 , in Documents in 1963, and in the Acquisition Department in 1961. In 1975 he became law librarian at the firm of Pillsbury, Madison, and Sutro in San Francisco.

ANNE MARIE FALSONE, assistant commissioner of Education for Libraries and Adult Services for the Colorado State Library, died earlier this year.

JEANNETTE HAGAN, former catalog librarian at the University of California, Los Angeles, died on February 10, 1988. She had served in the Catalog Department for 28 years before retiring in 1972 . Prior to 1943, she was employed in a number of governmental and agency libraries in Washington, D.C. and San Francisco, California, following her graduation from the School of Librarianship at the University of California, Berkeley. She had pioneered the processing of such new media as microforms, and was a nationally recognized authority on the bibliographic treatment of documents, both domestic and foreign. She served as the head of several sections in the Catalog Department and as assistant head of the Technical Services Department following its establishment. Hagan was active in library and state employee organizations, serving as president of the UCLA Library Staff Association, on the Descriptive Cataloging Committee, ALA, RTSD, and in several capacities in the California State Employees Association.

MARY REID LAKE, reference librarian at Lane College, Jackson, Tennessee, died August 5, 1988, in Peoria, Illinois.

MiLdRED Lowe, former director of the Division of Library and Information Science at St. John's University, Jamaica, New York, died in an automobile accident on August 22. Lowe had retired from her position in 1987, after serving 17 years as a professor of librarianship. She received her bachelor's degree from Brooklyn College, an MLS from Pratt Institute, and a doctorate in library science from Columbia University. She recently was recruiting new members to librarianship and lobbying for improved funding for New York State libraries. She was a Councilor-at-Large for the New York Library Association and active in METRO. She had received the Librarian of the Year award in the Spring of 1988 from the Long Island Library Conference. 